\title{
Implementation of Model Simulation in Improving Students' Motivation and Cognitive Ability
}

\author{
Anita Dwi Anggraini, Muhari, R.R. Nanik Setyowati \\ Universitas Negeri Surabaya \\ Surabaya, Indonesia \\ anitadwia30@gmail.com
}

\begin{abstract}
This study aims to improve students' motivation and cognitive ability through the implementation of model simulation. The subjects are fifth graders at SDN Wonorejo IV/315 in Tegalsari, Surabaya. This classroom action research used interview and observation to collect the research data. Data validity techniques used were source and time triangulation. Interactive analysis technique consisted of three components: data reduction, presentation of data and conclusion. Research procedure consisted of four stages: planning, action, observation, and reflection. The research process was done in two cycles, the first and second cycles. The result showed an increased motivation to learn civic education due to the implementation of model simulation. This can be seen from the increase in students' activities in learning. Percentage of students' learning outcomes which was initially only $\mathbf{4 0 . 6 5 \%}$ or as many as 13 students had succeeded minimum score (KKM) increased as many as $25 \%$ to $65 \%$ out of a total of 32 students. Thus, the total of the students who successfully fulfill KKM amounted to 21 . In the second cycle, the number of students who have succeeded KKM was $87.50 \%$ or 28 students.
\end{abstract} method.

Keywords-Motivation to learn, civic education, simulation

\section{INTRODUCTION}

One of big problems in education in Indonesia is low-quality education. Therefore, to solve low-quality education, we have to focus on the quality of learning. That kind of quality education can be realized if the learning process held and planned well. Of course, there are some components that support each other and connected so it can be contributed to the learning quality and result. Among students, teachers, materials, methods, learning resources, facilities and infrastructure and the cost.

SDN Wonorejo IV/315 as one of the educational institution which very honors the success of learning, so the students are produced are able to have a role in global competition. Civic education subject is a subject that focuses on various value formation in aspects of religion, sociocultural, language and tribes which is smart, skillful and have a good-characteristic as mandated by Pancasila and 1945 Constitution (UUD 1945) (Competency-based Curriculum, 2004).

According to Susanto(2013:227), civic education learning in elementary school as a learning process is aimed to help students to study well and form the whole human beings of Indonesia to build their national character. It is expected to lead a society that puts democracy in the life of a nation and state based on Pancasila, Constitution and moral apply in society.

But, unfortunately, in practice, this subject is less desirable and studied in the educational world because most formal educational institutions are more dominant on presentation of material cognitively and psychomotor. Civic education learning in SDN Wonorejo IV/315, the place where this research taken, still oriented with the monotonous knowledge-transfer method.

This is what causes the learning outcome not optimal, it can be seen from this indicator, as average fifth graders SDN Wonorejo IV/315's scores still below the required average, 75. The results of the early observation taken from student's condition are as follows:

1. Students look less enthusiastic about the subject. They look less enthusiastic to follow the learning activity.

2. Students lack of motivation to learn civic education. They look surfeited with the subject.

Based on that introduction, we can define a problem "Whether implementation of model simulation can improve fifth graders Wonorejo public elementary school IV/315 students' motivation and cognitive ability in learning civic education?

\section{LITERATURE REVIEW}

Simulation Model

One of the models that teachers can use is by simulation. Simulation came from the word "simulate" which means pretend to be or as if. And so "simulation" which means copying or just pretend[1]. It agrees with Ahmadi (2005) simulation means the action that just pretending. Based on Roestiyah [2] simulation is someone behavior to act like the person who intended. In order for someone to learn deeper about what other people demonstrate. In the learning process, in order to make students train give a role as other.

As a learning method, simulation can be interpreted as activities that reflect the actual situation. It means students 
with teacher guidance perform a role in simulated copies to illustrate actual events. Which is the method of learning is a method of making an imitation of something real. This method show symbols or equipment that displays the process of the event or its actual form (Yamin, 2004:73).

From the explanation above, it can be concluded that the simulation is a learning method that can be used to train students performing deed or behavior that describes the real condition. To practice problem-solving skills sourced from the reality of life.

\section{Step by step Model Simulation}

Based on Sanjaya (2008), steps that must be taken by teachers in using this method is as follows:

\section{1) Preparation of the simulation}

a) The teacher describes the problem to be simulated

b) The teacher assigns players involved in the simulation situation, the role to be played and the time allocation provided

c) The teacher gives the opportunity to ask especially the simulation player

\section{2) Implementation of the simulation}

a) Simulations begin to be played by cast groups

b) The other students followed by noticing

c) Teachers provide help to students who are on difficult

d) The simulation should be stopped when it reaches its peak. This is intended to engage students to think in a simulated matter.

\section{3) Closing}

a) Conducting discussions about the simulation and simulated material. The teacher encourages students to respond to the simulation process.

b) Formulate conclusion. To implement this method the teacher must prepare carefully the steps. So the desired result can be achieved. When the simulation is in progress, students are expected to record the ongoing events and can conclude what happened in the simulation.

\section{Principles of Simulation Model}

The principle of the simulation method according to Taniredja, et al (2011: 41), there are:

1. Performed by a group of students, each group gets the opportunity to carry out the same or different simulations

2. All students must be directly involved in accordance with their respective roles

3. The determination of topics matches the level of classroom ability

4. The simulation instructions are given first

5. In the simulation should be described as a complete situation

6. Cultivated integrated with some science
The same thing was also conveyed by B. Uno (2007: 29) about some principles that must be held by the teacher, there are:

1. Explanation: To simulate all players must understand the rules of the game. For that, the teacher should provide an explanation with as clear-clarity about the activities to be performed by students along with the consequences.

2. Supervise: Simulations are designed for specific purposes with certain rules and procedures. Therefore, teachers should monitor the simulation process so that it works well.

3. Train: In the simulation, players will experience errors. Therefore teachers should assist and advise, guidance, or direction so as to enable them not to make mistakes again.

4. Discussion: Discussion in reflection is very important. Therefore, after completing the simulation the teacher discusses several things: how far the simulation is in accordance with the real situation, what difficulties occur in the implementation of the simulation, what wisdom is taken from the implementation of the simulation and how to improve/improve the simulation etc.

\section{Cognitive Ability}

Cognitive by Sudarna (2014) cited Nunggalina (2016: 121) is a process that occurs internally in the central nervous system when people are thinking. In general, this ability is defined as an intellectual potential consisting of several stages, there are knowledge, comprehension, application, analysis, synthesis, and evaluation.

Discussing Cognitive means understanding what it takes to develop reasonableness. This theory emphasizes how or the process to optimize the rational aspects of a person.

The cognitive learning process involves a process of recognition or discovery. Cognitive learning by Karwono and Mularsih [3] includes inter-elemental associations, concept formation, problem-solving and problem-solving skills that further shape new behaviors.

Meanwhile, according to Piaget in Slavin [4], he divided the cognitive development of children and adolescents into four stages: motor sensory, preoperative, concrete operations, and formal operations. He believes that every child passes the stage in sequence and that no one can pass a stage. Although different children go through that stage at a somewhat different rate.

The following cognitive steps according to Piaget:

\section{Motor sensory (born-2 years)}

All children are born with an innate tendency to interact with their environment and to understand it. At first, the baby has an innate behavior called reflex motion such as lip movements to suck, and hands grasp when something is sticking. This is why during this stage babies and young 
children explore their world using their senses and motor skills.

\section{Preoperative (2-7 years)}

During this stage, the language and concept of the child develop at an incredible rate. However, many of their thoughts remain very primitive. This stage is the stage when the child learns to symbolize something within the mind. According to the Piaget, this stage follows the motor sensory stage and occurs between the ages of two and seven.

In this stage, the child will develop his language skills. They began to present objects around them with words and pictures. However, they still use intuitive reasoning, not logical. At the beginning of this stage, they tend to be egocentric. They do not understand where they belong to each other and how they are related. They are still struggling to understand how people feel around them. But along with maturation, their ability to understand others will improve.

\section{Concrete operations (7-11 years)}

Children in this stage can form concepts, see relationships, and solve problems. But only so far if they involve familiar objects and situations. There are several important processes in this stage, there are :

\section{a. Ordering}

Children are able to sort objects according to size, shape, or other characteristics. For example, when children are given objects of different sizes, they are able to sort from the largest to the small, or vice versa.

\section{b. Decentering}

In this stage, children begin to consider several aspects of a problem to solve it

\section{c. Reversibility}

That is the stage children who can begin to understand the number or objects can be changed, then back to the original state. For example, children can add up to $2+2$ total 4 , and 4-2 total 2.

\section{d. Conservation}

That understands that the quality, length or number of objects is not related to the arrangement or appearance of the object or object. For example, if a child is given a glass the size of the same water. They will know when the water is poured into another glass of different sizes, then the water in the glass remains as much as the water in the other glass.

\section{e. Removal of egocentricity}

That is the ability to see things from the other person's point of view.

\section{Formal operation (11-Adults)}

In this stage where one can face the hypothetical situation in an abstract and logical reasoning. Piaget focuses on how language development is influential in the process of thinking. His theory emphasizes maturity and cognitive development based on age stages.

According to him, cognitive development aims to obtain psychological structures so that people think logically and able to reason actual problems. He views the child as an active organism that always evolves within itself with a pattern of patterns. He also saw that cognitive development is the result of the child's efforts in responding and understanding his world.

The basic principle in the theory is that children construct their own understanding. Understanding is not a copy of reality. For that reason, learning is a process in which a child, through assimilation and accommodation, develops a structure of knowledge to be of value.

The cognitive domain according to Thoha (1991: 28) has the following characteristics:

\section{Able to translate}

2. Be able to interpret and describe verbally.

\section{Able to understand}

\section{Civic education}

Civic education is a subject that is used as a vehicle to develop and preserve the noble and moral values rooted in the culture of the Indonesian nation. This value is expected to be manifested in the form of daily student behavior, both as individuals and as a society. (Susanto, 2015: 225)

According to Azyumardi (2005) in Susanto (2015)

This study uses collaborative research. According to Asrori et al [5], collaborative action research is a research where researchers cooperate with several parties, such as school principals, classroom teachers, and students. The purpose according to Pardjono [6] is to change a group, organization or society that has various problems towards a better situation.

From the above discussion, it can be concluded that the meaning of civic education is a process of teaching and learning in order to assess human relationships with humans, in organized associations, as well as between individuals with the state used as a vehicle for developing and preserving noble and moral values rooted in Indonesian national culture.

Civic learning in primary school is intended as a teaching and learning process in order to help learners to learn well and to form a complete human being in the formation of national character. With the hope that in order to create a social order that put democracy in the life of nation and state based on Pancasila, the Constitution, and norms that prevail in society. 
According to Soemantri cited Ubaedillah and Rozak (2013: 15) state that the civic as a science of citizenship that discusses human relationships with humans in organized associations as well as between individuals with the state. Civic education is characterized by activities already programmed by the school. This activity includes learning activities that can foster good behavior. Citizenship education is conducted with activities related to experiences associated with real life as in family and society.

, civic education is education that examines and discusses government, constitution, democratic institutions, human rights, rights and obligations of citizens and democratic process.

This research type is descriptive research qualitative and quantitative, that is research which describes reality or fact of field with aim to describe activity of teacher and student. As well as the responses were given by students in the learning process, the goal is to solve real problems that occur in the classroom and improve the professionalism of teachers in their profession (Kusnandar, 2008: 45)

\section{RESEARCH METHODS}

\section{Research Subject}

Subjects in this study were 5th-grade students of SDN Wonorejo IV / 315 Surabaya. The subjects in detail are the civic education which amounts to. The selection of this subject is based on:

1. Lack of student motivation in following the civic education lesson

2. Students' learning outcomes, especially the civic education lessons with a success rate of only $60 \%$ of the students.

\section{Place of Research}

This research was conducted in SDN Wonorejo IV / 315 Surabaya. Reasons researchers choose in the school are:

1. The openness of the principal and teachers who are the profession's friends to give permission and want to collaborate in solving problems with student motivation in the aspect of the implementation of a simulation model in improving motivation and cognitive ability of civic education (Civics) grade V students in the school.

2. Researchers want to develop teaching materials Civics using the more innovative simulation model to improve students' cognitive motivation and ability.

\section{Action Implementation Procedures}

According to Arikunto et al [7], recycling in classroom action research must go through several stages: plan planning, action, observation and evaluation of observations and evaluation, reflection, and so on until success criteria are met. The details of the flow are as follows:

\section{1) Planning Action}

In this stage, which must be implemented by teachers, among others, there are:

a) Analyze the curriculum to find out the basic competencies and design the lesson plans

b) Perform pre-cycle activities i.e. observation in the classroom to find problems in the field.

c) Plan the steps of the learning process with the simulation model in cycle I. But the implementation is still flexible and can be changed in implementation.

d) Design instruments as guidelines for implementation and assessment of students' cognitive learning outcomes.

The benchmark of the implementation of this research is on the cognitive learning outcomes of students on the subject of education Citizenship (Civics) class V. Criteria are made into the cognitive domain by Taxonomy Bloom is from the level of knowledge, comprehension, and application.

\section{2) Implementation of Action}

The implementation phase of this action is an application of preparedness planning. The implementation of this research follows the classroom action research steps that consist of several cycles. However, the planning that is made is only flexible and can be changed in the implementation, Asrori et al [5]. The details in this activity are as follows:

a) The teacher designates some students to study the scenario

b) Teachers form groups of students

c) The teacher conveys the learning objectives

d) The teacher appoints students to play a role

e) Students discuss in groups

f) Students present the results of the discussion

g) Teachers and students hold guidance and conclusions

h) Teachers and students reflect

3) Observing and Evaluating Process and Results

This stage aims to observe the activities of teachers and students. That is done by some observers, namely classroom teachers and peers to observe the implementation of learning. This is done to determine the effect of improvement and improvement of the learning process. In addition, classroom teachers also collect the necessary data, to conduct an assessment of the results of the action, with the format of worksheets that have been provided.

\section{4) Reflecting}

Activities undertaken at this stage are to analyze, evaluate, and discuss data that must be obtained through observation. 
At this stage, the researcher considers the results and impacts of the actions taken. If the data has not reached the success criteria, then the researcher performs the improvement steps to be applied in the next cycle [7]. If it is in accordance with the criteria of success, then researchers can continue to the next cycle. Or if the results have been very satisfying, in accordance with the plan, then research can be considered successful.

\section{Research design}

The design in this study consists of several cycles. Each cycle consists of several meetings. Before doing the researcher make the research design first. The research design is as follows:

\section{First, cycle \\ a. Action plan}

The things that need to be prepared in this action plan include:

1) Researchers develop RPP (Learning Implementation Plan) in accordance with the curriculum

2) Preparing materials and tools to be used in accordance with the learning materials

3) Develop assessment guidelines based on reference books

b. Implementation of the action

Implementing lessons based on scenarios in RPP (Learning Implementation Plan) prepared by the researcher.

\section{c. Observation}

The observation is done by the researcher as an observer and the implementing teacher directly to observe the learning process by observing the process and behavior of the students. Focus more on Grade $\mathrm{V}$ students on improving motivation and cognitive ability of civic education (Civics)

\section{d. Reflection}

Reflection is done after completion of the action. Researchers conduct discussions with students about things that still need to be fixed or deemed sufficient. And do a discussion on the implementation of the next action plan

\section{Second cycle}

The second cycle is implemented if the first cycle has not succeeded. The stages in this cycle are the same as the stages in the first cycle. But in this cycle, there has been an improvement on things that need to be improved.

\section{Data collection technique}

According to Arikunto [7] data collection methods is a way that can be used by researchers to collect data. In this research, the method used is observation and documentation.

\section{a. Observation Method}

According to Marzuki [8] observation is a study by way of observation and recording systematically to the symptoms or phenomena being investigated. Using this method the researcher obtained physical data, the geographical location of the school and the facilities (facilities and infrastructure) of the school

\section{b. Documentation Method}

In Arikunto [7] documentation is a method used to find data about things or variables in the form of notes, transcript books, newspapers, inscriptions, meeting minutes, agenda and so on. This method is used by researchers to obtain data about the state of teachers, organizational structure and student state data. In this study, documentation techniques are used to present an overview when learning occurs.

\section{c. Measurement of test results}

Measurement of learning result test done with the aim to know the improvement of student's motivation and achievement. The test involves a preliminary test / pre-action knowledge test, which will be used to determine the mastery of the concept of the subject matter before giving the action. In addition to the initial tests are also carried out tests at each end of the action.

\section{Analysis and Validity of data}

According to Nazir [9], Data analysis is a very important part of the scientific method because the analysis of data can be given useful purpose in solving research problems. Data analysis basically processes quantitative as well as qualitative information in such a way that the results of the information are more meaningful. Classroom action research is a case study in one class. So it cannot be generalized in other conditions and classes. Then the data analysis simply by describing the data collected.

In analyzing the data collected from various methods, the authors used descriptive qualitative methods with percentages. This method is used to express and analyze data that is qualitative. How to analyze data by using the descriptive method with the percentage is qualitative data that exist in quantitative, is in the form of a percentage, just to make decision making easier. Then after knowing the percentage is qualitative again. And conclusions can be drawn.

Descriptive data analysis intends to describe or summarize the results of the study. This can be done through the reduction of qualitative data (description-narrative) using the code, images, diagrams etc. With this analysis, the researcher sees the achievement of the objectives by looking at the improvement of certain aspect conditions or even the achievement of the limit on certain mastery [6].

Qualitative data collected from the observation sheets that have been collected in Civics learning. The data is in the 
form of student activity during the learning process so that it can be known to increase the motivation and cognitive aspects of students in Civics. According to Sudjana (2009, 132) The calculation and presentation of student activeness can be calculated using the following formula:

$$
\mathrm{P}=\mathrm{FN} \mathrm{X} \mathrm{100 \%}
$$

$\mathrm{P}=$ Percentage

$\mathrm{F}=$ Number of scores obtained

Maximum Score count

Guidelines for success criteria used are indicators of success in the cognitive aspects Indicators include:

a. If at least $80 \%$ of students get the KKM score.

b. If the implementation of learning $80 \%$ done well with a minimum score of 75 .

c. Student learning outcomes are a significant increase from the first cycle to the next cycle.

\section{RESULT AND DISCUSSION}

Motivation can be interpreted as the power of a person who can cause the level of willingness in carrying out activities either from within itself or outside the individual. The learning process will be successful when students have motivation in learning. Therefore, teachers need to foster motivation in learning to students continuously to obtain optimal learning outcomes.

The result of the research indicates that the model simulation increased the students' learning motivation significantly. This can be seen from the increase in student activity in learning. Student learning outcomes which at the initial finding was only $40.65 \%$ or as many as 13 students who have passed KKM increased to $25 \%$ to $65.65 \%$ of the total 32 students. So that students who passed KKM in the first cycle amounted to 21 Students. In the second cycle, students who passed KKM was $87.50 \%$ or 28 students.

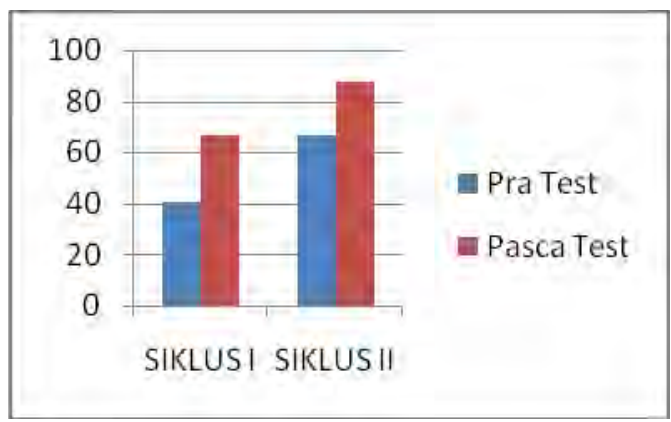

Graph of Master activity and student learning outcomes

(Total Number of Students 32 with details of 12 women and 20 men)

Through the graph, the indicator of achievement has been met so that the research can be stopped and completed. From the results of the above research, it proves that the application of the simulation method can improve students' learning motivation in civic education learning.

\section{CONCLUSION}

Changes or learning experienced by students in a better or positive direction in this study looks at the learning outcomes of research subjects. Most students have conducted their learning activities and experienced improvements or changes rather than learning outcomes before implementing the simulation method. The magnitude of a change or improvement of learning outcomes experienced by students of each individual is different. The greater the increase in learning outcomes the better the teaching and learning activities. Aspects of learning outcomes studied in this study are the cognitive aspects of students in Civics Education lessons, which includes the ability to use concepts and rules in solving problems using simulation methods.

\section{Reference}

[1] A. Arief, Pengantar ilmu metodologi pendidikan islam. Jakarta: Ciputat Pers, 2002.

[2] N. K. Rustiyah, Strategi belajar mengajar. Jakarta: Rineka Cipta, 1991.

[3] Karwono and H. Mularsih, Belajar dan pembelajaran. Depok: Rajawali Pers, 2017.

[4] R. E. Slavin, Psikologi pendidikan, teoridan praktik. Jakarta: PT. Indeks, 2011.

[5] M. Asrori and H. Rasyid, Penelitian tindakan kelas peningkatan kompetensi profesional guru. Yogyakarta, 2007.

[6] S. Pardjono, K. S. Paidi, and E. P. Sukamti, "Panduan Penelitian Tindakan Kelas," Yogyakarta Lemb. Penelit. Univ. Negeri Yogyakarta, 2007.

[7] S. Arikunto, Penelitian tindakan kelas. Jakarta: Bumi Aksara, 2006.

[8] Marzuki, Metode riset. Yogyakarta: BPEFE_USI, 1998.

[9] M. Nazir, Metodologi penelitian. Jakarta: Ghalaindo, 1999. 